\title{
Urgences
}

\section{Le baby dull d'Éva}

\section{Anne Bernier}

Numéro 13, mars 1986

\section{Éclats d'atelier}

URI : https://id.erudit.org/iderudit/025233ar

DOI : https://doi.org/10.7202/025233ar

Aller au sommaire du numéro

\section{Éditeur(s)}

Urgences

\section{ISSN}

0226-9554 (imprimé)

1927-3924 (numérique)

Découvrir la revue

\section{Citer ce document}

Bernier, A. (1986). Le baby dull d'Éva. Urgences, (13), 74-75.

https://doi.org/10.7202/025233ar d'utilisation que vous pouvez consulter en ligne.

https://apropos.erudit.org/fr/usagers/politique-dutilisation/ 


\section{LE BABY DULL D'ÉVA Anne Bernier}

dans mon ventre, une femme cultivée, labourée par l'ultime apostrophe de débauche, se vautre humide et confiante, ose un grand écart de sexe syntaxique qui lui fait tendre l'oreille et le clitoris, la pousse à hurler au suivant, I'homme précédent devinant bien que celui d'après fait déjà partie du passé tu jouis donc je suis, si mielleux de sperme et de fleur de peau qu'à le dire mes lèvres se collent à mes cuisses entrouvertes par une souplesse de gestes tout autant latents que le désir qui s'arrête et se poursuit à la fois, que la virgule qui bande m'excite et me perd sous l'encre épaisse et filamenteuse qui ira loin dans la vie, puisque rien ne se perd ni davantage ne se crée sans fantasmes, ne se crée que l'alcôve sacrée, béni ce paradis contracepté, idéalisé par la pucelle, éprouvé en couches puis en de maintes prouesses anodines, goûtées, comparées, évaluées, ô combien évaluées nos tristes et désespérées performances de volcan en érection engloutissant un amoncellement de terres chaudes et psalmodiantes, des mots pour la tendresse* et tant d'autres pour les fesses

mes mains sur ton nez qui cherche mon sexe, j'orgasme de volupté, je goûte l'amer et le ciel à la fois, crains l'agréable attendu, et pendant que mon cri traverse le mur, j'éveille le cadran qui éjacule sur la rôtie de l'aînée, brûle d'une envie qui glisse, crémeuse de pulsations et de rythmes ponctués de points orgasmiques, con en dégustation, orgie de confitures et de fromage, mes seins comme des oranges pressées et juteuses, les yeux m'en tournent et l'oeuf trop cuit me réchauffe I'oreiller, sa main à la poêle ou sur ma vulve en attente, suis patiente et exigeante, suis l'amante de la prison de Nantes qui rêve de son souffle sur mon cou, dans mon cul, de l'aube claire jusque sans points de suspension, ni plus ni moins l'absolution, le terme à venir assécher l'eau que je prête et que parfois je donne, lorsque les péchés sont véniels comme les doigts qui ne savent pas, qui me tuent et me fixent au brancard, resuscitons Lazare qui frémit et me regarde sans amouras- 
mer, nie et crayonne, ovule peut-être, invente et sue le désir du coït ininterrompu aux soupirs stériles ligaturés et vasectomisés, louons les condoms mignons et comptons sur le bout de nos doigts si lourds d'odeurs, sexe sans baby doll, sexe dull baby, sexe à virgules mouillées d'orgasmes d'hippopotames en rut, la pomme d'Eva est à croquer, les paradis à sauter et tous les robots à pénis gonflables à débrancher, je pompe l'extase et recommence sans points ni virgules

* employée ici comme préambule au cul, comme ce l'est toujours inévitablement 